PSICOLOGIA, SAÚDE \& DOENÇAS, 2021, 22(1), 218-229

ISSN - 2182-8407

Sociedade Portuguesa de Psicologia da Saúde - SPPS - www.sp-ps.pt

DOI: http://dx.doi.org/10.15309/21psd220119

\title{
HOW HAPPY CHILDREN AND ADOLESCENTS FEEL DURING HOSPITALIZATION IN A PEDIATRIC UNIT?
}

\author{
Teresa Freire ${ }^{1}$, Gabriela Ferreira ${ }^{1}, \&$ Almerinda Pereira ${ }^{2}$ \\ ${ }^{1}$ Department of Applied Psychology, School of Psychology, University of Minho, Campus de Gualtar, Braga, \\ Portugal, tfreire@psi.uminho.pt, gabrielaferreira@psi.uminho.pt \\ ${ }^{2}$ Pediatric Department, Hospital of Braga, Braga, Portugal, almerindabarrosopereira@gmail.com
}

\begin{abstract}
This study aims to analyse: i) the relationship between sociodemographic, clinical and psychological variables, and feeling happy during hospitalization; ii) the differences on feeling happy during hospitalization according to clinical variables; iii) and the contribution of socio-demographic, clinical and psychological variables, to feeling happy during hospitalization. The participants were 101 children and adolescents hospitalized (51.5\% are girls) in the Pediatric Unit of a Hospital in the northern region of Portugal. Ages ranged between 10 and 17 years $(M=$ $14, S D=2.35)$. Participants answered the following questionnaires: Hope Scale for Children; Positive and Negative Affect Scale; and Depression, Anxiety and Stress Scale - Children. Feeling happy during hospitalization was assessed by a single item asking how they feel since they are hospitalized, using the "faces" scale from 1 (extremely unhappy) to 7 (extremely happy). The assessment took place in a single moment and fulfilled all the ethical and deontological requisites. Feeling happy during hospitalization was not significantly associated with sociodemographic (e.g. gender, age) and clinical variables (e.g. chronic disease, type of hospitalization), except with the scheduling of hospitalization. It was found that a scheduled hospitalization, higher levels of positive affect, and greater hope in general contributed to higher feelings of happiness during hospitalization, explaining $30 \%$ of the variance. The knowledge of the individual variables that contribute to children and adolescents' feelings of happiness during hospitalization may bring clinical implications for individual intervention, out or inside the hospital setting.
\end{abstract}

Keywords: Hospitalization, children and adolescents, happiness, affect, hope, distress.

\section{QUÃO FELIZES SE SENTEM CRIANÇAS E ADOLESCENTES HOSPITALIZADAS EM UMA UNIDADE PEDIÁTRICA?}

RESUMO: Este estudo pretende analisar: i) a relação entre variáveis sociodemográficas, clínicas e psicológicas e sentir-se feliz durante a hospitalização; ii) as diferenças no sentimento de felicidade durante a hospitalização em função de variáveis clínicas; iii) e a contribuição das variáveis sociodemográficas, clínicas e psicológicas para o sentimento de felicidade durante a hospitalização. Participaram 101

Department of Applied Psychology, School of Psychology, University of Minho, Campus de Gualtar, 4710-057 Braga, Portugal, email: tfreire@psi.uminho.pt 
crianças e adolescentes hospitalizados (51,5\% raparigas) na Unidade Pediátrica de um Hospital da região Norte de Portugal. As idades variaram entre 10 e 17 anos $(M=14$, $D P=2,35)$. Os participantes responderam aos seguintes questionários: Escala de Esperança para Crianças; Escala de Afeto Positivo e Negativo; e Escala de Depressão, Ansiedade e Stress - Crianças. Sentir-se feliz durante a hospitalização foi avaliado por um único item que questionava como se sente desde que está internado, por meio da escala de "faces" de 1 (extremamente infeliz) a 7 (extremamente feliz). A avaliação ocorreu em um único momento e cumpriu todos os requisitos éticos e deontológicos. Sentir-se feliz durante a hospitalização não se associou significativamente com variáveis sociodemográficas nem clínicas, exceto com a programação da hospitalização. A hospitalização programada, níveis mais elevados de afeto positivo e maior esperança contribuíram para maior sentimento de felicidade durante a hospitalização, explicando $30 \%$ da variância. O conhecimento das variáveis individuais que contribuem para o sentimento de felicidade de crianças e adolescentes durante a hospitalização pode trazer implicações clínicas para a intervenção individual, dentro ou fora do ambiente hospitalar.

Palavras-Chave: Hospitalização, crianças e adolescentes, felicidade, afeto, esperança, distress.

Recebido em 09 de janeiro de 2021/ Aceite em 28 de março de 2021

Motta and Enumo (2004) have previously identified hospitalizations as a factor that influences childhood and adolescent development, often negatively interfering with their quality of life. These authors found that some contributing factors include confronting an unknown and restrictive environment (often characterized by play privation), experiencing a loss of autonomy and control, separation from friends and family, routinely having school interrupted, and enduring the discomfort from various treatments and invasive procedures. For example, chronic disease often requires long, daily and complex treatments in the hospital context, which compromises the wellbeing of children and adolescents (Soares et al., 2011).

The Evidence-Based Practice Statement approved by the Child Life Council (Koller, 2008) presents a set of variables associated with children's ability to deal with hospitalization, which includes: i) children variables (e.g. temperament, age and gender); ii) family variables (e.g. parental stress and anxiety and family characteristics); iii) disease variables (e.g. length of hospitalization); iv) and medical experiences (e.g. previous experiences of hospitalization).

\section{Reactions to hospitalization}

The reactions that happen more often in this population when dealing with hospitalization are anxiety and fear, stress, pain, discomfort, and sleep and appetite disorders (Baldini \& Krebs, 1999; Mussa \& Malerbi, 2008). Regressive behaviors may also occur (Baldini \& Krebs, 1999). Studies that assessed hospitalized children found that they experienced a wide range of negative emotional states such as unhappiness, sadness, nervousness, fear, anger, boredom, loneliness, frustration, distrust, uncertainty, shame, and guilt, among others (Salmela et al., 2010; Wilson et al., 2010). Other literature has even suggested that negative emotions may contribute to higher length of infections and delaying of wound healing (cf. Kiecolt-Glaser et al., 2002).

Even with this surmounting evidence on the negative impact of hospitalization, there are little, if any, national or international studies assessing feelings of happiness or well-being in hospitalized children and adolescents. Only some literature suggests that children and adolescents' hospitalization leads to negative reactions with an impact on their positive development, and that 


\section{HAPPINESS OF HOSPITALIZED CHILDREN/ ADOLESCENTS}

individual resources, such as personality and coping style, might have a positive influence on the regulation of immune and endocrine functioning, and this can act as a buffer against the effects of negative emotions, and indirectly improving health (Kiecolt-Glaser et al., 2002). Following these studies, it becomes relevant, first of all, to analyze what kind of individual characteristics children and adolescents have that may influence the way they feel during the hospitalization (e.g., feeling happy during hospitalization) and, therefore, allow them to cope better with this potentially disruptive experience.

\section{Positive and negative affect}

Positive affect has been suggested as having benefits not only at short-term but also at long-term. Indeed, it has been associated with life satisfaction, better health, and longevity (Cohen et al., 2003; Danner et al., 2001; Fredrickson, 2013; Pavot \& Diener, 2008). Besides, longitudinal studies revealed that positive affect in infancy and adolescence was found to be associated with higher life satisfaction (Coffey et al., 2015), less relationship problems, and lower levels of depression and anxiety, in adulthood, even after controlling the baseline levels of these measures (Kansky et al., 2016). Negative affect in infancy and adolescence, on the other hand, was not significantly associated with life satisfaction (Coffey et al., 2015), relationship problems or psychological adjustment (Kansky et al., 2016), in adulthood.

\section{Hope}

Hope is considered a crucial resource in the life of adolescents, especially when regarding the health-illness continuum (Dufault \& Martocchio, 1985) and predicting positive vital outcomes, such as well-being (Esteves et al., 2013). In particular, hope has been associated with greater health behaviors, life satisfaction, positive affect (e.g. joy), and well-being. Furthermore, these variables have been found to be outcomes of hope in both healthy and ill adolescents (cf. Esteves et al., 2013). On the other hand, hope has been negatively associated with depression, anxiety, healthyrisk behaviors and negative affect (e.g. sadness) (cf. Esteves et al., 2013). Indeed, studies suggested that adolescents with higher levels of hope showed skills that allow them to find several routes to achieve their goals, are more resilient when confronted with adverse events, interpret obstacles as challenges and deal better with psychological symptoms (e.g. anxiety and depression) (Stoyles et al., 2015).

\section{Happiness}

Regarding the relationship between happiness and health, Moreira and Dupas (2003) assessed the perceptions of health and disease in children aged between 7 and 12 years, both at school and in the hospital setting. It was found that these children attributed similar meanings to health, regardless of which group they belonged to. More specifically, children in schools considered health as being crucial to life, making them feeling free, and contributing to their well-being and happiness. In the hospital, the children felt that health was extremely valuable, providing them energy to live and to do what they like; they just feel happy having health and, therefore, they just want to recover quickly (Moreira \& Dupas, 2003). It has also been suggested that happiness was associated with better physical health (Argyle, 1997; cf. Lyubomirsky et al., 2005). This relationship can be bidirectional: positive emotions prevent the activation of the autonomic nervous system, whose reactions have cumulative adverse effects on health; conversely, happy individuals are more likely to adopt healthy behaviors and avoid unhealthy or risky behaviors (cf. Lyubomirsky et al., 2005; Sabatini, 2014). In addition, literature has suggested that young people who reported to feel happier 
and more satisfied with their life showed better physical and mental health, higher self-esteem, better skills to solve problems and tend to be more resistant to stress (Huebner, 2004; Park, 2004).

\section{Current study}

In addition to the mentioned psychological variables, the present study will also analyze variables associated with children's ability to deal with hospitalization: age, gender, severity of the diagnosis that lead to the hospitalization, previous experiences of hospitalization, scheduling and type of hospitalization.

This study aims to analyze: i) the relationships between socio-demographic (gender and age), clinical (chronic disease, first hospitalization, scheduling and type of hospitalization), psychological variables (positive and negative affect, psychological distress, and hope), and feeling happy during hospitalization; ii) the differences on feeling happy during hospitalization according to clinical variables; iii) the predictor role of socio-demographic, clinical and psychological variables, on feeling happy during hospitalization.

\section{METHOD}

\section{Participants and Procedure}

This is a cross-sectional study, since the assessment occurred in a single moment. The sample consisted of Portuguese children and adolescents, hospitalized in the Pediatric Unit of a Hospital in the northern region of Portugal. This study meets all the ethical and deontological requirements at national and international levels. The Ethics Committee of the Hospital, where data collection took place, approved the study. Inclusion criteria comprised: having 10 years old or more, being hospitalized in the Pediatric Unit of the Hospital for at least 48 to 72 hours and have cognitive skills to answer the questionnaires. The researcher contacted the hospitalized children/adolescents that met inclusion criteria, as well as their parents, and invited them to participate in the study. They were informed about the aims of the research, the confidentiality of the data and the voluntary character of their participation. Both children/adolescents and their parents signed an informed consent, and then, filled out the battery of self-report questionnaires. Clinical data was provided by the physician team through the number of the clinical process of the children/adolescent at the Hospital database.

\section{Measures}

Socio-demographic and clinical questionnaire. It is composed by several questions to characterize the sample in socio-demographic (gender, age, education level, nationality, with whom they live) and clinical terms (presence of chronic disease [no/yes], first hospitalization [no/yes], scheduling of hospitalization [scheduled/emergency], type of hospitalization [medical/surgical]). The clinical questionnaire also comprised a measure of Diagnosis Related Groups (DRG) that is a system of classification of patients hospitalized, based on the main diagnosis (the one that, after the study of the patient, was responsible for its admission to the hospital), the secondary diagnoses (all other diagnoses associated with the clinical condition of the patient, which may lead to the existence of complications or comorbidities), the procedures performed, the age and sex of the patient, the destination after discharge.

Children's Hope Scale (Marques et al., 2009). This scale assesses the hope's thought regarding the goals, in children and adolescents, and can be applied in clinical or non-clinical populations. It 


\section{HAPPINESS OF HOSPITALIZED CHILDREN/ ADOLESCENTS}

is composed by six items and the answer is given in a six-point scale, from 1 (none of the time) to 6 (all of the time), whose total scores may range from 6 to 36 points. Higher results indicate higher levels of hope. In the Portuguese version, the Cronbach alpha was .81. In this sample, the alpha was .79 .

Positive and Negative Affect Scale -Reduced Portuguese Version (PANAS-VRP; Galinha et al., 2014). This scale consists of 10 items related to emotions, divided into two dimensions: positive affect and negative affect. It was asked to individuals to assess in what extent they feel these emotions in their life in general, on a scale ranging from 1 (nothing or very little) to 5 (extremely). Thus, higher results on negative affect indicate displeasure and subjective discomfort; whereas in positive affect correspond to pleasure and subjective well-being. The Portuguese version showed Cronbach alphas of .86 for the positive affect scale and .89 for the negative affect scale (Galinha \& Ribeiro, 2005). In this sample, alphas were .70 for positive affect and .75 for negative affect.

Depression, Anxiety and Stress Scale - Children (EADS-C; Leal et al., 2009). This scale consists of 21 items, such as in the version for adults, divided in three dimensions with 7 items each anxiety, depression, and stress. The items were submitted to cognitive debriefing, being reformulated to become more easily understandable to children, but these minor changes did not affect the validity of the instrument content. It was asked to children to respond to items based on how they felt during the past week, in a 4-point Likert scale, ranging from 0 (did not apply to me at all) to 3 (applied to me most of the time). Higher results indicate more negative affective states in the respective dimension. This scale presented Cronbach alphas of .74 for the Stress scale, .75 for Anxiety and .78 for the Depression (Leal et al., 2009). In this sample, Cronbach alphas of .81 for the Stress scale, .75 for Anxiety and .86 for the Depression were obtained.

Feeling happy during hospitalization. It consists in a single-item measure that asks children and adolescents to classify the way they feel since they were hospitalized. The answer is given in a faces scale, varying from 1 (extremely unhappy) to 7 (extremely happy).

\section{Data analysis}

Frequencies, means and standard deviations were calculated in order to characterize the sample in terms of socio-demographic, clinical and psychological variables. To analyze the relationship between feeling happy during hospitalization and socio-demographic, clinical and psychological variables, it was performed Pearson's Correlation Coefficients. Point-Biserial Correlation Coefficient was performed to assess the relationship between feeling happy during hospitalization and gender. T-tests for independent samples were conducted to examine the differences on feeling happy during hospitalization according to clinical variables. To explore the variables that contribute to feeling happy during hospitalization, a hierarchical regression was conducted (method enter). In the first step the socio-demographic and clinical variables associated with the dependent variable were included, in the second step the positive psychological variables, and in the third step the negative ones.

\section{RESULTS}

\section{Sample characteristics}

The sample is composed by 101 Portuguese children and adolescents, hospitalized in the Pediatric Unit of a Hospital in the northern region of Portugal. The characterization of the sample is presented at Table 1. 
Table 1. Descriptive Statistics for Socio-demographic and Clinical Variables $(N=101)$

\begin{tabular}{|c|c|c|c|c|}
\hline Continuous measure & Min & Max & Mean & $S D$ \\
\hline Age & 10 & 17 & 13.98 & 2.35 \\
\hline Number of previous hospitalizations & 0 & 18 & 1.14 & 2.17 \\
\hline Diagnosis Related Groups (DRG) weight & .22 & 4.72 & .95 & .80 \\
\hline Categorical measure & & & & $\%$ \\
\hline \multicolumn{5}{|l|}{ Gender } \\
\hline Boys & & & & 48.5 \\
\hline Girls & & & & 51.5 \\
\hline \multicolumn{5}{|l|}{ Education level } \\
\hline $4^{\text {th }}$ grade & & & & 6.0 \\
\hline $5^{\text {th }}$ and $6^{\text {th }}$ grade & & & & 25.0 \\
\hline $7^{\text {th }}, 8^{\text {th }}$ and $9^{\text {th }}$ grade & & & & 33.0 \\
\hline $10^{\text {th }}, 11^{\text {th }}$ and $12^{\text {th }}$ grade & & & & 36.0 \\
\hline \multicolumn{5}{|l|}{ Nationality } \\
\hline Portuguese & & & & 95.0 \\
\hline Others & & & & 5.0 \\
\hline \multicolumn{5}{|l|}{ Type of family } \\
\hline Nuclear & & & & 64.4 \\
\hline Extended & & & & 15.8 \\
\hline Rebuilt & & & & 5.0 \\
\hline Single-parent & & & & 14.9 \\
\hline \multicolumn{5}{|l|}{ Chronic disease } \\
\hline No & & & & 71.3 \\
\hline Yes & & & & 28.7 \\
\hline \multicolumn{5}{|l|}{ First hospitalization } \\
\hline No & & & & 49.0 \\
\hline Yes & & & & 51.0 \\
\hline \multicolumn{5}{|l|}{ Scheduling of hospitalization } \\
\hline Scheduled & & & & 33.7 \\
\hline Emergency & & & & 66.3 \\
\hline \multicolumn{5}{|l|}{ Type of hospitalization } \\
\hline Medical & & & & 31.7 \\
\hline Surgical & & & & 68.3 \\
\hline \multicolumn{5}{|l|}{ Reason for hospitalization (based on ICD-10) } \\
\hline I. Certain infectious and parasitic diseases & & & & 3.0 \\
\hline II. Neoplasms & & & & 2.0 \\
\hline \multicolumn{5}{|c|}{ III. Diseases of the blood and blood-forming organs and certain disorders involving the } \\
\hline immune mechanism & & & & 0 \\
\hline IV. Endocrine, nutritional and metabolic diseases & & & & 0 \\
\hline V. Mental and behavioural disorders & & & & 1.0 \\
\hline VI. Diseases of the nervous system & & & & 1.0 \\
\hline VII. Diseases of the eye and adnexa & & & & 0 \\
\hline VIII. Diseases of the ear and mastoid process & & & & 3.0 \\
\hline IX. Diseases of the circulatory system & & & & 3.0 \\
\hline X. Diseases of the respiratory system & & & & 8.9 \\
\hline XI. Diseases of the digestive system & & & & 19.8 \\
\hline XII. Diseases of the skin and subcutaneous tissue & & & & 6.9 \\
\hline XIII. Diseases of the musculoskeletal system and connective tissue & & & & 10.9 \\
\hline XIV. Diseases of the genitourinary system & & & & 5.0 \\
\hline
\end{tabular}




\section{HAPPINESS OF HOSPITALIZED CHILDREN/ ADOLESCENTS}

XV. Pregnancy, childbirth and the puerperium 0

XVI. Certain conditions originating in the perinatal period 0

XVII. Congenital malformations, deformations and chromosomal abnormalities 13.9

XVIII. Symptoms, signs and abnormal clinical and laboratory findings, not elsewhere $\quad 3.0$ classified

XIX. Injury, poisoning and certain other consequences of external causes 14.9

XX. External causes of morbidity and mortality 2.0

XXI. Factors influencing health status and contact with health services $\quad 2.0$

$\begin{array}{ll}\text { XXII. Codes for special purposes } & 0\end{array}$

\section{Preliminary analyses}

Descriptive measures of the psychological variables were calculated. Feeling happy during hospitalization varied between 1 and $7(M=5.02, S D=1.14)$; positive affect between 9 and $25(M$ $=17.66, S D=3.53)$ and negative affect between 5 and $18(M=8.64, S D=3.31)$; hope between 17 and $36(M=26.98, S D=4.57)$; depression symptoms between 0 and $18(M=3.19, S D=3.69)$, anxiety symptoms between 0 and $15(M=3.39, S D=3.39)$, and stress between 0 and $20(M=5.01$, $S D=4.25)$. In average, this sample of hospitalized children/ adolescents reported high levels of positive affect and hope in general, and to feel happier during hospitalization, as well as lower levels of negative affect, depression, anxiety and stress symptoms (high or low, meaning above or below average values).

Relationships between feeling happy during hospitalization and sociodemographic and clinical variables

Results of Point-Biserial Correlation Coefficient revealed that feeling happy during hospitalization was not significantly associated with gender $\left(r_{p b}=-.02, p=.86\right)$. In addition, Pearson's Correlation Coefficient showed that feeling happy during hospitalization was not significantly associated with age $(r=.03, p=.74)$, number of previous hospitalizations $(r=.02, p=$ $.85)$, and Diagnosis Related Groups (DRG) weight $(r=.09, p=.38)$.

\section{Relationships between feeling happy during hospitalization and psychological variables}

Results of Pearson's Correlation Coefficient revealed that feeling happier during hospitalization was significantly associated with higher levels of positive affect $(r=.40, p<.001)$ and greater hope $(r=.46, p<.001)$; but not with negative affect $(r=.02, p=.86)$, depressive symptoms $(r=-.18, p$ $=.07)$, anxiety symptoms $(r=-.17, p=.09)$, and stress symptoms $(r=-.10, p=.31)$.

\section{Differences on feeling happy during hospitalization according to clinical variables}

The results of the differences on feeling happy during hospitalization according to clinical variables are presented at Table 2. In sum, children and adolescents reported to feel happier during hospitalization, when the hospitalization was scheduled. 
Teresa Freire, Gabriela Ferreira, \& Almerinda Pereira

Table 2. Differences in feeling happy during hospitalization according to clinical variables.

\begin{tabular}{|c|c|c|c|c|c|c|c|c|c|c|c|c|}
\hline & \multicolumn{2}{|c|}{ Chronic Disease } & \multicolumn{4}{|c|}{ First hospitalization } & \multicolumn{2}{|c|}{$\begin{array}{l}\text { Scheduling of the } \\
\text { hospitalization }\end{array}$} & \multicolumn{4}{|c|}{ Type of hospitalization } \\
\hline & $\begin{array}{c}\text { No } \\
(n=72) \\
M(S D)\end{array}$ & $\begin{array}{c}\text { Yes } \\
(n=29) \\
M(S D)\end{array}$ & $t(99)$ & $\begin{array}{c}\text { No } \\
(n=49) \\
M(S D)\end{array}$ & $\begin{array}{c}\text { Yes } \\
(n=51) \\
M(S D)\end{array}$ & $t(98)$ & $\begin{array}{c}\text { Scheduled } \\
\begin{array}{c}(n=34) \\
M(S D)\end{array}\end{array}$ & $\begin{array}{c}\text { Emergency } \\
\quad(n=67) \\
M(S D)\end{array}$ & $t(99)$ & $\begin{array}{c}\text { Medical } \\
(n=32) \\
M(S D)\end{array}$ & $\begin{array}{c}\text { Surgical } \\
(n=69) \\
M(S D)\end{array}$ & $t(99)$ \\
\hline $\begin{array}{l}\text { Feeling happy during } \\
\text { hospitalization }\end{array}$ & $\begin{array}{c}5.08 \\
(1.17)\end{array}$ & $\begin{array}{c}4.86 \\
(1.06)\end{array}$ & .88 & $4.96(1.06)$ & $5.08(1.23)$ & -.52 & $\begin{array}{l}5.41 \\
(.82)\end{array}$ & $\begin{array}{c}4.82 \\
(1.23)\end{array}$ & $2.53 *$ & $\begin{array}{c}4.84 \\
(1.22)\end{array}$ & $\begin{array}{c}5.10 \\
(1.10)\end{array}$ & -1.06 \\
\hline
\end{tabular}

$* p<.05$ 


\section{HAPPINESS OF HOSPITALIZED CHILDREN/ ADOLESCENTS}

\section{Variables that contribute to feeling happy during hospitalization}

The results of the final model of the hierarchical regression revealed that scheduling of the hospitalization, positive affect, and hope were significantly associated with feeling happy during hospitalization (Table 3). Thus, scheduled hospitalizations, higher levels of positive affect, and greater hope were associated with greater feelings of happiness during hospitalization. The final model explained $30 \%$ of the variance $\left(\operatorname{Adj} . R^{2}=.25\right)$.

Interestingly, positive affect only became significant in model 3, when negative psychological variables (negative affect and anxiety symptoms) were added to clinical (scheduling of the hospitalization and DRG weight) and positive psychological variables (positive affect and hope).

Table 3. Hierarquical regression analysis for variables contributing to feelings of happiness during hospitalization $(N=101)$.

\begin{tabular}{|c|c|c|c|c|c|c|c|c|c|}
\hline \multirow[b]{2}{*}{ Variable } & \multicolumn{3}{|c|}{ Model 1} & \multicolumn{3}{|c|}{ Model 2} & \multicolumn{3}{|c|}{ Model 3} \\
\hline & $B$ & $S E B$ & $\beta$ & $B$ & $S E B$ & $\beta$ & $B$ & $S E B$ & $\beta$ \\
\hline $\begin{array}{l}\text { Scheduling of the } \\
\text { Hospitalization }\end{array}$ & -.57 & .24 & $-.24 *$ & -.43 & .21 & $-.18^{*}$ & -.44 & .21 & $-.18 *$ \\
\hline DRG weight & .09 & .14 & .06 & -.01 & .13 & -.003 & -.01 & .13 & -.01 \\
\hline Positive affect & & & & .06 & .03 & .19 & .07 & .03 & $.23 *$ \\
\hline Hope & & & & .08 & .03 & $.33 * *$ & .07 & .03 & $.28 *$ \\
\hline Negative affect & & & & & & & .04 & .04 & .13 \\
\hline Anxiety symptoms & & & & & & & -.06 & .03 & -.17 \\
\hline$R^{2}\left(\operatorname{Adj} . R^{2}\right)$ & & $.06(.0$ & & & $.27(.2$ & & & $.30(.2$ & \\
\hline$F$ for change in $R^{2}$ & & $3.37^{*}$ & & & $13.89^{*}$ & & & 1.52 & \\
\hline
\end{tabular}

$\mathrm{DRG}=$ Diagnosis Related Groups

$* p<.05 ; * * * p<.001$

\section{DISCUSSION}

Despite the inexistence of studies that assess children and adolescents' happiness during hospitalization, literature showed the existence of several negative reactions to hospitalization (Baldini \& Krebs, 1999; Motta \& Enumo, 2004; Mussa \& Malerbi, 2008; Salmela et al., 2010), suggesting that feelings of happiness could be lower than in contexts different from hospitals.

Contrary to what was expected, our results showed this sample of children and adolescents, on average, felt happy during hospitalization. This result can be related to some other obtained results on individual variables, as it is the case of the participants' perceptions of greater hope and positive affect, in general. In our sample, positive affect and hope were significant predictors of higher feelings of happiness during hospitalization. In fact, considering empirical evidence, literature on hope has suggested its association with greater life satisfaction, positive affect and well-being (cf. Esteves et al., 2013). Moreover, studies also suggested that hope is considered a psychological strength that may act as a buffer when facing negative and stressful life events (Stoyles et al., 2015; Valle et al., 2006), such as hospitalization.

Interestingly, positive affect only became significant, when all the variables at study are included in the regression model, which claims attention to the importance of understanding positive functioning in a whole, i.e., only when we considered all the spectrum of clinical, positive, and negative variables, positive affect arises as a predictor of feeling happy during hospitalization.

The results also showed that feeling happy during hospitalization was not associated with sociodemographic (e.g. gender, age) or clinical variables (e.g. chronic disease, type of hospitalization), 
with the exception of having or not having a scheduled hospitalization for inpatient treatment. In our study, feeling happier was associated with having a scheduled hospitalization. In fact, studies suggested that some variables associated with the hospitalization can have a direct impact on the way children cope with hospitalization and its procedures and, indirectly, on their feelings of happiness. It seems that when the hospitalization is scheduled, children and adolescents have time to prepare, cognitive and emotionally, for an interruption in their routine. Like this, they can reframe their values associated to their perception of health, so making relevant the emergence of an intentional sense of hope and, therefore, make the experience of hospitalization not so disruptive, as it could be in the case of an emergency hospitalization.

This study also controlled the severity of the pathology that leads to hospitalization, because it was considered as an important factor influencing children and adolescents' feelings of happiness. However, it was not significantly associated with feelings of happiness in this sample, which suggest that feeling happy during hospitalization does not depend from the severity of the pathology, but from the interaction of a set of variables - individual and clinical/contextual ones. Moreover, we propose that hospital context has important specificities that should be targeted when promoting the children and adolescents' well-being and happiness during hospitalization.

\section{Limitations and future directions}

This study has some limitations that should be addressed and considered in future studies in order to validate the obtained results: the sample should be extended, in terms of number and diversity of individuals; to use a longitudinal design instead of a cross-sectional one, looking at how feelings of happiness change during the period of hospitalization; and to further analyze the role of context and physical conditions (e.g. equipment, recreational activities) in order to know the impact of the hospital setting on the way participants feel happy.

To our knowledge, this is the first national or international study to assess the feelings of happiness in children and adolescents during hospitalization. This becomes pertinent since happiness and health are associated, both through physiological and behavioral pathways, with literature suggesting that individual resources might have positive effects on immune system functioning and might also play a buffer role against the negative emotions. Thus, individual resources can positively contribute to the recovery of children and adolescents, improving their perception of good health.

A better understanding of the commitment generated by the hospitalization and of the individual variables of children and adolescents that contribute to feeling happy during hospitalization may have clinical and medical implications at the level of the individual intervention or the development of programs to promote well-being, inside or outside the hospital setting. For example, inside the hospital, literature has shown that interventions focused on ludic activities (e.g. playing, storytellers) had positive effects both at physical and emotional levels (Motta \& Enumo, 2004; Mussa \& Malerbi, 2008). On the other hand, outside the hospital, interventions should promote positive affect and hope through programmes focused on the development of adaptive coping skills (Valle et al., 2006) that help these young people to deal more effectively when confronted with specific medical situations, perceived by them as negative and stressful, and that foster the positive development of these children and adolescents. Feeling happy during hospitalization should be considered a relevant pediatric variable when considering children and adolescents' medical treatments. 


\section{HAPPINESS OF HOSPITALIZED CHILDREN/ ADOLESCENTS}

\section{ACKNOWLEDGMENTS}

We would like to thank to the children and adolescents that accepted to participate in this study, as well as to their parents, for their collaboration. We would like to thank to the physicians of the Pediatric Unit where this study was conducted for their collaboration, Dr. Francisca Calheiros-Trigo and Dr. Marta Ribeiro Silva. The authors also thank to Keith Gissubel for improving the use of English in the manuscript.

\section{FUNDING}

This study was conducted at the Psychology Research Centre (PSI/01662), School of Psychology, University of Minho, supported by the Foundation for Science and Technology (FCT) through the Portuguese State Budget (UIDB/PSI/01662/2020).

\section{REFERENCES}

Argyle, M. (1997). Is happiness a cause of health? Psychology \& Health, 12, 769-781. https://doi.org/10.1080/08870449708406738

Baldini, S. M., \& Krebs, V. L. J. (1999). A criança hospitalizada [The hospitalized child]. Pediatria (São Paulo), 21(3), 182-190.

Coffey, J. K., Warren, M. T., \& Gottfried, A. W. (2015). Does infant happiness forecast adult life satisfaction? Examining subjective well-being in the first quarter century of life. Journal of Happiness Studies, 16, 1401-1421. https://doi.org/10.1007/s10902-014-9556-X

Cohen, S., Doyle, W. J., Turner, R., Alper, C. M., \& Skoner, D. P. (2003). Sociability and susceptibility to the common cold. Psychological Science, 14(5), 389-395.

Danner, D. D., Snowdon, D. A., \& Friesen, W. V. (2001). Positive emotions in early life and longevity: Findings from the nun study. Journal of Personality and Social Psychology, 80, 804813. https://doi.org/10.1037/0022-3514.80.5.804.

Dufault, K., \& Martocchio, B. C. (1985). Hope: Its spheres and dimensions. Nursing Clinics of North America, 20, 379-391.

Esteves, M., Scoloveno, R. L., Mahat, G., Yarcheski, A., \& Scoloveno, M. A. (2013). An integrative review of adolescent hope. Journal of Pediatric Nursing, 28, 105-113. https://doi.org/10.1016/j.pedn.2012.03.033

Fredrickson, B. L. (2013). Positive emotions broaden and build. In E. Ashby Plant \& P. G. Devine (Eds.), Advances on experimental social psychology (Vol. 47, pp. 1-53). Academic Press.

Galinha, C., Pereira, C. R., \& Esteves, F. (2014). Versão reduzida da Escala Portuguesa de Afeto Positivo e Negativo - PANAS-VRP: Análise factorial confirmatória e invariância temporal. Revista Psicologia, 28(1), 53-65.

Galinha, I., \& Ribeiro, J. (2005). Contributions for the study of the Portuguese version of Positive and Negative Affect Schedule (PANAS): II - Psychometric study. Análise Psicológica, 23, 219227.

Huebner, E. S. (2004). Research on assessment of life satisfaction of children and adolescents. Social Indicators Research, 66, 3-33.

Kansky, J., Allen, J. P., \& Diener, E. (2016). Early adolescent affect predicts later life outcomes. Applied Psychology: Health and Well Being, 8, 192-212. https://doi.org/10.1111/aphw.12068. 
Kiecolt-Glaser, J. K., McGuire, L., Robles, T. F., \& Glaser, R. (2002). Emotions, morbidity, and mortality: New Perspectives from Psychoneuroimmunology. Annual Review of Psychology, 53, 83-107.

Koller, D. (2008). Child life assessment: Variables associated with a child's ability to cope with hospitalization (Child Life Council Evidence-Based Practice Statement). Available at: http://www.childlife.org/files/EBPAssessmentStatement-Complete.pdf.

Leal, I. P., Antunes, R., Passos, T., Pais-Ribeiro, J., \& Maroco, J. (2009). Estudo da Escala de Depressão, Ansiedade e Stresse para Crianças (EADS-C). Psicologia, Saúde \& Doenças, 10(2), 277-284.

Lyubomirsky, S., King, L., \& Diener, E. (2005). The benefits of frequent positive affect: Does happiness lead to success? Psychological Bulletin, 131, 803-855. https://doi.org/10.1037/00332909.131.6.803

Marques, S. C., Pais-Ribeiro, J. L., \& Lopez, S. J. (2009). Validation of a Portuguese version of the Children's Hope Scale. School Psychology International, 30, 538-551. https://doi.org/10.1177/0143034309107069

Moreira, P. L., \& Dupas, G. (2003). Significado de saúde e de doença na percepção da criança [The meaning of health and disease from the child's point of view]. Revista Latino-Americana de Enfermagem, 11(6), 757-762.

Motta, A. B., \& Enumo, S. R. F. (2004). Brincar no hospital: Estratégia de enfrentamento da hospitalização infantil [Playing in the hospital: Coping strategy in child hospitalization]. Psicologia em Estudo, 9(1), 19-28.

Mussa, C., \& Malerbi, F. E. K. (2008). O impacto da atividade lúdica sobre o bem- estar de crianças hospitalizadas [The impact of playing on the well-being of hospitalized children]. Psicologia: Teoria e Prática, 10(2), 83-93.

Park, N. (2004). The role of subjective well-being in positive youth development. Annals of the American Academy of Political and Social Science, 591, 25-39.

Pavot, W., \& Diener, E. (2008). The satisfaction with life scale and the emerging construct of life satisfaction. The Journal of Positive Psychology, 3(2), 137-152.

Sabatini, F. (2014). The relationship between happiness and health: Evidence from Italy. Social Science \& Medicine, 114, 178-187. https://doi.org/10.1016/j.socscimed.2014.05.024

Salmela, M., Aronen, E. T., \& Salanterä, S. (2010). The experience of hospital-related fears of 4- to 6-year-old children. Child: care, health and development, 37, 719-726. https://doi.org/10.1111/j.1365-2214.2010.01171.x

Soares, A. H. R., Martins, A. J., Lopes, M. C. B., Britto, J. A. A., Oliveira, C. Q., \& Moreira, M. C. N. (2011). Qualidade de vida de crianças e adolescentes: Uma revisão bibliográfica [Quality of life of children and adolescents: A bibliographical review]. Ciência \& Saúde Coletiva, 16, $3197-$ 3206. https://doi.org/10.1590/S1413-81232011000800019

Stoyles, G., Chadwick, A., \& Caputi, P. (2015). Purpose in life and well-being: The relationship between purpose in life, hope, coping, and inward sensitivity among first-year University Students. Journal of Spirituality in Mental Health, 17, 119-134. https://doi.org/10.1080/19349637.2015.985558

Valle, M. F., Huebner, E. S., \& Suldo, S. M. (2006). An analysis of hope as a psychological strength. Journal of School Psychology, 44, 393-406. https://doi.org/10.1016/j.jsp.2006.03.0050

Wilson, M. E., Megel, M. E., Enenbach, L., \& Carlson, K. L. (2010). The voices of children: Stories about hospitalization. Journal of Pediatric Health Care, 24, 95-102. https://doi.org/10.1016/j.pedhc.2009.02.008 